\title{
Simulator Tekanan Darah: Minimalisasi Pengaruh Laju Inflasi dan Deflasi Terhadap Simulasi Osilasi
}

\author{
ALFIN DARWONGSO ${ }^{1}$, FUAD UGHI ${ }^{1 *}$, SIDDIQ WAHYU HIDAYAT ${ }^{2}$ \\ ${ }^{1}$ Biomedical Engineering Swiss German University \\ 2Pusat Penelitian Sistem Mutu dan Teknologi Pengujian - \\ Lembaga Ilmu Pengetahuan Indonesia \\ Email: *fuad.ughi@sgu.ac.id
}

Received 8 November 2018 | Revised 30 November 2018 | Accepted 7 Januari 2019

\begin{abstract}
ABSTRAK
Simulator tekanan darah biasa digunakan sebagai nilai referensi dalam mengevaluasi tensimeter otomatis (NIBP monitor). Penelitian sebelumnya menunjukkan bahwa simulator tekanan darah dapat dibuat dengan menggunakan micro air pump berbasis motor dc sebagai aktuator. Namun, hasil simulasi yang dihasilkan berbeda untuk setiap merek tensimeter. Hasil analisa menunjukkan bahwa laju inflasi dan deflasi yang berbeda mempengaruhi karakteristik simulasi. Studi ini bertujuan untuk mengembangkan firmware simulator baru berdasarkan nilai pulse width modulation (PWM) dan gradien inflasi-deflasi untuk meminimalkan pengaruh tersebut, sehingga simulator dapat memberikan hasil yang sama untuk berbagai jenis dan merek NIBP monitor. Validasi dengan simulator referensi dan evaluasi dalam kondisi statis dan dinamis menunjukkan simulator yang dikembangkan cukup andal untuk melakukan pemeriksaan awal, termasuk evaluasi pengulangan hasil tensimeter otomatis.
\end{abstract}

Kata kunci: NIBP monitor, PWM, NIBP simulator, gelombang osilasi, laju inflasi, laju deflasi

\section{ABSTRACT}

Blood pressure simulators are commonly used as reference values in evaluating NIBP (noninvasive blood pressure) monitors. Prior research shows that an NIBP simulator can be made using dc motor based micro air pump as the actuator. However, the simulator yield different results for different brands of NIBP monitor. The analysis result showed that inflation/deflation rates do affect the simulation's characteristic. This research aims to develop a new simulator firmware based on pulse width modulation (PWM) values and rising-falling slope to minimize the corresponding effect so that the developed simulator could generate the same result for various types and brands of NIBP monitor. Validation using a reference simulator and evaluation in static and dynamic conditions showed that the developed simulator is reliable enough to do a quick pre-checks, including assessing the repeatability of NIBP monitors.

Keywords: NIBP Monitor, PWM, NIBP Simulator, Oscillometric Waveform, Inflation Rate, Deflation Rate 


\section{PENDAHULUAN}

Tensimeter otomatis yang banyak beredar di pasaran sebagian besar menggunakan metode osilometrik. Metode ini memanfaatkan osilasi tekanan pada manset tensimeter yang disebabkan oleh denyut pada pembuluh darah untuk menentukan nilai tekanan darah tanpa memerlukan perangkat tambahan atau penilaian dari personil medis. Salah satu masalah dalam penggunaan alat tensimeter otomatis adalah evaluasi atau kalibrasi perangkat tersebut untuk memberikan pengukuran tekanan darah yang tepat dan akurat (Balestrieri, Daponte, \& Rapuano, 2009). Proses evaluasi dapat dilakukan melalui perangkat simulator yang dikenal sebagai Simulator Tekanan Darah Non-Invasif (NIBP Simulator). Harga perangkat ini cukup mahal (mencapai 141 juta rupiah untuk simulator merek FLUKE Biomedical, Model BPPM2L / ECG-SHK pada November 2017), sehingga dapat menjadi kendala untuk berbagai industri kecil atau rumah sakit kelas bawah yang perlu untuk melakukan pemeriksaan cepat atau mengevaluasi perangkat mereka. Oleh karena itu, pengembangan simulator berbiaya rendah bisa menjadi solusi untuk masalah ini.

Gregorius Alvin Dewanto sebelumnya telah melakukan penelitian awal terkait dengan pengembangan simulator berbiaya rendah, yakni dengan harga $\pm 2,5$ juta rupiah yang dibuat dengan menggunakan komponen-komponen elektronik sederhana untuk nilai preset tekanan darah $120 / 80 \mathrm{mmHg}$. Namun, dalam pengujian simulator tersebut, hasil simulasi yang baik dan tepat hanya terbatas pada alat tensimeter merek tertentu. Hal ini disebabkan karena program yang dibuat untuk melakukan simulasi mengikuti sifat dari merek tensimeter OMRON, yang akhirnya membuat hasil simulasi hanya bagus pada tensimeter merek OMRON (Dewanto, 2016). Nico Antonio Santoso mengembangkan versi penelitian Dewanto dengan penambahan nilai preset dan mode simulasi baru, yaitu metode inflating. Namun untuk memberikan hasil yang sama, diperlukan program (firmware) simulasi berbeda untuk tiap merek. Ini berbeda dari pengujian dengan simulator NIBP komersial, yang menghasilkan hasil yang sama terlepas dari semua jenis atau merek monitor NIBP (Santoso \& Ughi, 2017).

Gagasan dari metode pada program yang digunakan oleh kedua penelitian tersebut di atas adalah dengan menemukan beberapa target osilasi untuk tiap nilai tekanan tertentu (Dewanto, 2016) (Santoso \& Ughi, 2017). Ilustrasi pada Gambar 1 menjelaskan bagaimana nilai selisih ditentukan dari suatu grafik osilasi. Nilai target ini digunakan untuk menentukan nilai tekanan osilasi yang perlu diberikan oleh simulator pada titik tekanan tertentu hingga mencapai nilai target osilasi tersebut. Hal ini dapat dilakukan dengan menentukan nilai "selisih" (Difference) yang didapat dari nilai osilasi pada tekanan target dikurangi dengan nilai osilasi awal (Initial Oscillation Value).

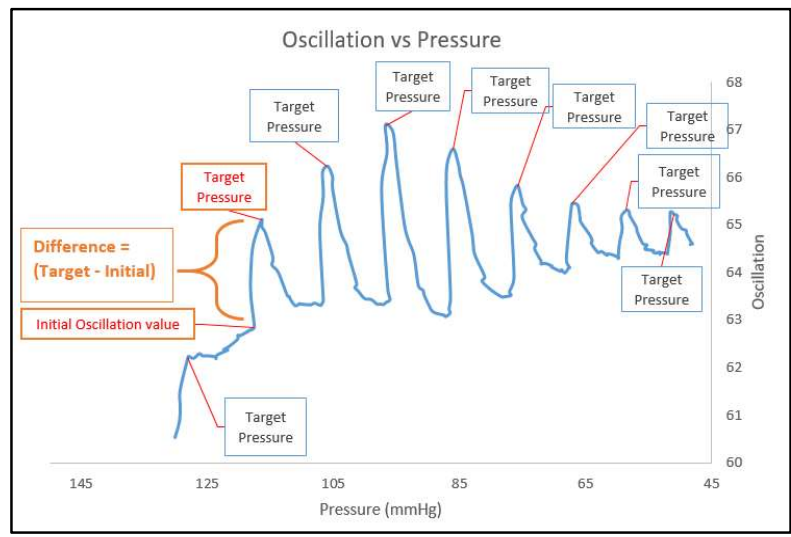

Gambar 1. Penentuan Nilai Perbedaan dari Grafik Osilasi terhadap Tekanan 
Metode ini bekerja dengan memberikan daya motor (nilai PWM) berdasarkan perbedaan antara nilai osilasi target dan nilai osilasi awal. Namun, ada beberapa kasus yang ditunjukkan pada Gambar 2 yang membuktikan bahwa metode ini tidak ideal untuk digunakan untuk berbagai jenis atau merek monitor NIBP.

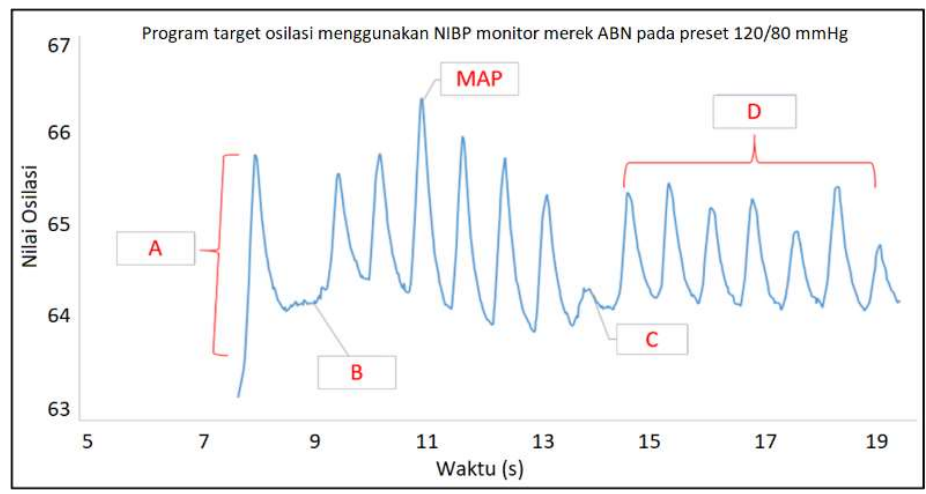

Gambar 2. Osilasi yang Dihasilkan dengan Metode Target Osilasi

Dengan menggunakan nilai target osilasi yang tetap, diharapkan hasilnya akan selalu sama untuk setiap pengukuran. Namun, dari sejumlah pengukuran dan analisis, ditemukan bahwa nilai osilasi awal (initial oscillation value) dapat berbeda-beda untuk setiap NIBP monitor dan juga dapat berbeda untuk setiap pengukuran (kasus A). Sehingga untuk beberapa kasus seperti kasus $B$ dan kasus $C$ pada gambar diatas, di mana nilai osilasi awal sama dengan nilai target (perbedaan $=0$ ) atau melebihi tekanan target (perbedaannya minus), tidak akan ada daya yang diberikan kepada motor, dan motor akan berhenti bekerja untuk waktu tertentu sehingga osilasi pun tidak terjadi. Sedangkan pola osilasi tidak beraturan (kasus D) terjadi ketika monitor tidak dapat menemukan hasil karena osilasi yang diberikan tidak cukup jelas.

Hal ini diduga karena setiap monitor NIBP otomatis memiliki laju inflasi atau deflasi yang berbeda yang mungkin memiliki pengaruh besar terhadap performa simulator, sehingga hasil simulasi yang dideteksi oleh monitor NIBP berbeda jauh dari yang diinginkan. Oleh karena itu, tujuan dari penelitian ini adalah untuk mengembangkan satu firmware simulator yang dapat meminimalkan efek tersebut dan menghasilkan hasil yang sama untuk berbagai merek monitor NIBP.

\section{METODOLOGI}

Studi ini menggunakan referensi dari simulator komersial yang terdapat di laboratorium Elektromedik, Pusat Penelitian Sistem dan Mutu Teknologi Pengujian (P2SMTP) - Lembaga Ilmu Pengetahuan Indonesia (LIPI). Simulator referensi dan sistem yang dirancang lalu digunakan untuk menguji empat NIBP monitor yang berbeda. Hasilnya kemudian dibandingkan untuk mengevaluasi performa simulator yang dirancang. Perangkat keras yang digunakan merupakan perangkat keras yang sama yang digunakan oleh dua penelitian sebelumnya, (Dewanto, 2016 \& Santoso, 2017) dengan sensor tekanan dikalibrasi ulang sebelumnya.

\subsection{Validasi Tensimeter Otomatis (NIBP Monitor)}

Empat merek berbeda (OMRON HEM 7203, ABN DU-120, Dr. Care HL888, dan Family Dr. TD3124) dievaluasi menggunakan sebuah referensi simulator (NIBP Simulator merek FLUKE Biomedical tipe BP Pump 2). Tiga NIBP monitor (OMRON, ABN, Dr. Care) merupakan tipe deflating (mengukur tekanan darah ketika tekanan pada manset berkurang), sedangkan satu NIBP monitor (Family Dr.) merupakan tipe inflating (mengukur tekanan darah ketika tekanan 
pada manset bertambah). Foto pada Gambar 3 menunjukkan tipe NIBP Monitor yang digunakan pada studi ini. Uji akurasi untuk setiap perangkat dilakukan dengan mengacu ke Standar Nasional Indonesia tentang spesifikasi NIBP monitor pada SNI IEC 80601-2-30:2014 (Badan Standardisasi Nasional, 2014).

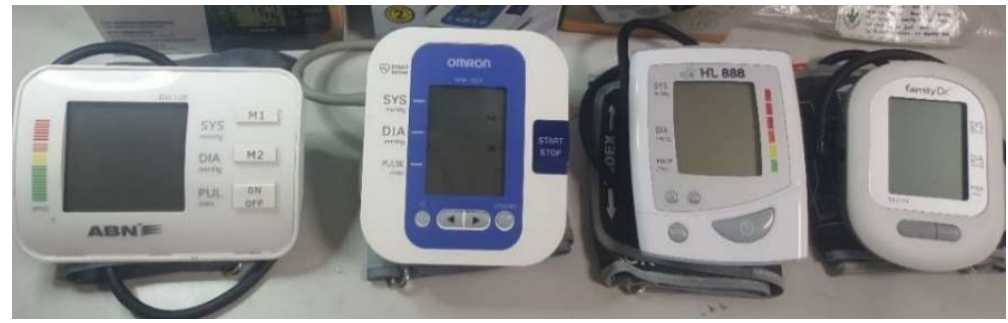

Gambar 3. Empat Merek Tensimeter Otomatis yang Digunakan

Uji validasi ini dibagi menjadi dua fase (uji akurasi dan uji pengulangan), dengan masingmasing mencakup tes untuk mode Neonatal (70/40 - 140 beat per minute atau bpm) dan mode Normal (120/80 - 80 bpm) menggunakan manset eksternal. Dalam uji akurasi, total 40 hasil (20 untuk setiap tes - uji pertama dan uji kedua) diperoleh untuk setiap mode (Neonatal dan Normal) dari masing-masing perangkat, dan rentang pengukuran harus kurang dari atau sama dengan $\pm 3 \mathrm{mmHg}$ dari pembacaan untuk tekanan darah sistolik (SBP) dan tekanan darah diastolik (DBP). Perbedaan rata-rata hasil yang dihitung dalam Tes 1 dan Tes 2 dibandingkan sebagai uji pengulangan, dan hasilnya tidak boleh melebihi batas $\pm 3 \mathrm{mmHg}$.

\subsection{Blok Diagram Simulator yang Dikembangkan}

Perangkat keras simulator yang dikembangkan, diilustrasikan pada blok diagram di Gambar 4.

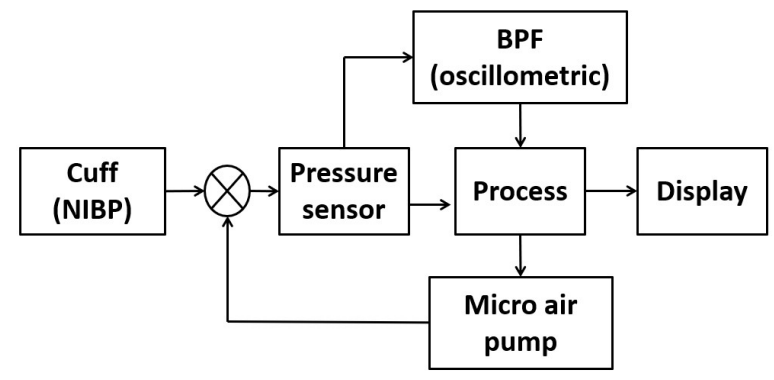

Gambar 4. Blok Diagram Simulator NIBP

Prinsip kerjanya secara singkat adalah sebagai berikut, cuff(manset) NIBP monitor yang akan dievaluasi, disambungkan dengan air splitter, sehingga tekanan udara yang dipompa oleh NIBP monitor akan terhubung dengan simulator NIBP. Pada simulator NIBP, jalur tekanan udara dibagi lagi untuk dihubungkan ke sensor tekanan dan micro air pump. Displaydigunakan untuk menampilkan preset tekanan darah yang akan disimulasikan. Sensor tekanan akan membaca tekanan udara pada manset, kemudian micro air pump akan memberikan osilasi tekanan sesuai dengan tekanan udara pada saat itu, untuk menyimulasikan osilasi yang dihasilkan oleh denyut pada pembuluh darah. Gambar 5 mengilustrasikan penggunaan simulator yang dikembangkan ketika mengevaluasi NIBP monitor. 


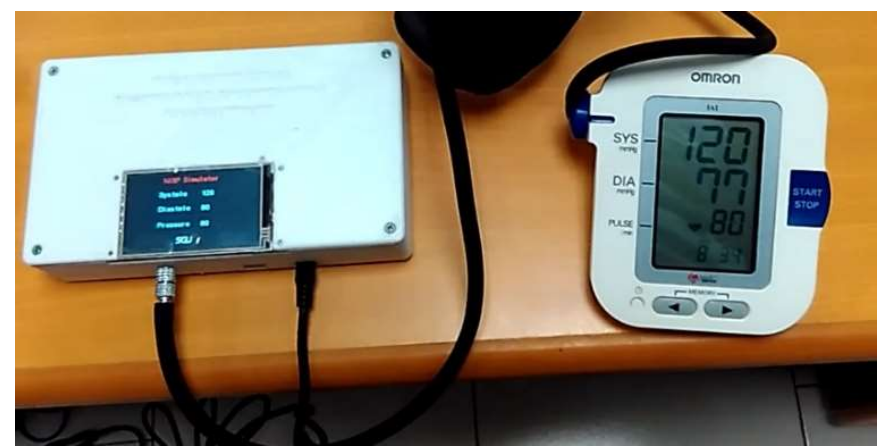

Gambar 5. Ilustrasi Penggunaan Simulator yang Dikembangkan

\subsection{Kalibrasi Sensor Tekanan}

Sensor tekanan yang digunakan (MPX5100GP) dikalibrasi menggunakan voltmeter dan tensimeter manual merkuri. Nilai tegangan dicatat untuk setiap kenaikan tekanan $2 \mathrm{mmHg}$. Kalibrasi dilakukan sebanyak tiga kali pengukuran dari 0 hingga $300 \mathrm{mmHg}$, yang merupakan tingkat rentang tekanan yang diperlukan untuk menguji alat tensimeter menurut International Organization of Legal Metrology OIML R16-2 Recommendations (International Organization of Legal Metrology, 2002).

\subsection{Data Referensi}

Pengambilan data referensi dilakukan menggunakan referensi yang sama (simulator FLUKE Biomedical). Lima standar preset tekanan darah (SBP / DBP: 80/50, 100/65, 120/80, 150/100, 200/150 dengan denyut nadi $80 \mathrm{bpm}$ ) digunakan dalam pengambilan data referensi untuk setiap monitor. Sejumlah 30 sampel diambil untuk setiap preset tekanan darah dan untuk setiap monitor. Hal ini untuk memberikan analisis dan perhitungan yang akurat seperti yang direkomendasikan oleh Probability and Statistical Inference (Hogg \& Tanis, 1977).

Semua data pengukuran yang telah direkam dianalisis menggunakan program Microsoft Excel menjadi dua grafik, yakni grafik tekanan terhadap waktu dan osilasi terhadap waktu seperti diilustrasikan oleh grafik pada Gambar 6.

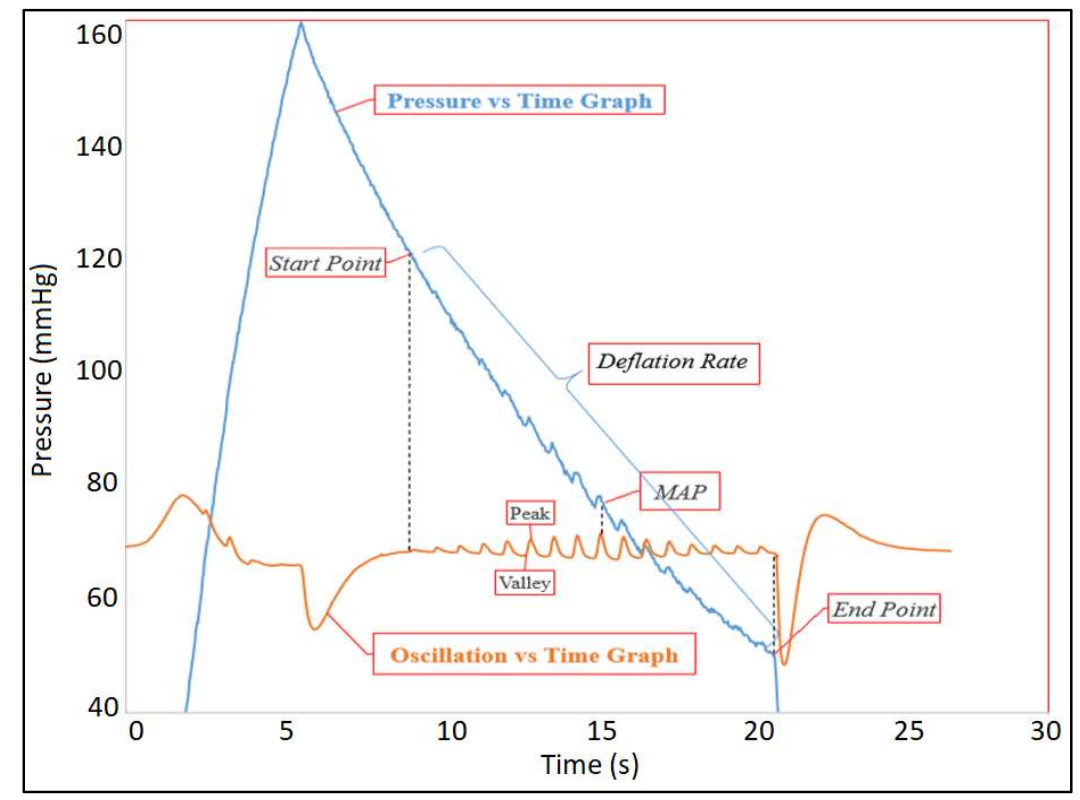

Gambar 6. Analisis Bentuk Gelombang Sinyal

Berikut merupakan lima parameter utama yang dianalisis dari grafik yang diperoleh. 
1. Start Point: Titik tekanan dimana proses osilasi dimulai (dalam $\mathrm{mmHg}$ ).

2. End Point. Titik tekanan dimana proses osilasi berakhir (dalam $\mathrm{mmHg}$ ).

3. MAP (mean arterial pressure): Titik tekanan pada amplitudo osilasi tertinggi di dalam satu proses osilasi (dalam $\mathrm{mmHg}$ ).

4. Deflation/Inflation rate: Laju penurunan/kenaikan tekanan dimulai dari waktu dimulainya proses osilasi hingga berakhirnya proses osilasi.

5. Valley-Peak duration: Jumlah waktu yang diperlukan untuk menyelesaikan satu siklus osilasi (lembah-puncak).

Modus naik terjadi dari titik mula proses osilasi hingga titik MAP, sementara modus turun terjadi dari titik MAP hingga titik akhir proses osilasi. Laju deflasi atau inflasi (Deflation/Inflation Rate) dianalisis untuk mengetahui pengaruh laju yang berbeda terhadap performa dan hasil simulasi. Durasi waktu dari lembah ke puncak serta durasi waktu dari puncak ke lembah digunakan untuk menentukan durasi menyala/ON dan durasi mati/OFF pada motor micro air pump. Dengan mengatur kecepatan rotasi motor dc (saat kondisi ON) pada micro air pump menggunakan PWM (pulse width modulation), sinyal osilasi dapat dibuat dari kombinasi motor ON dan OFF.

\subsection{Algoritma Perangkat Lunak}

Gagasan dari algoritma perangkat lunak pada studi ini adalah untuk menemukan nilai PWM terbaik pada nilai tekanan tertentu pada setiap preset tekanan darah. Berbeda dari metode target osilasi pada penelitian sebelumnya, nilai PWM yang digunakan pada tiap nilai tekanan akan tetap, sehingga osilasi yang dihasilkan untuk tiap monitor NIBP akan berbeda.

Nilai PWM diatur sedemikian rupa untuk membentuk envelope osilasi berbentuk gunung dengan puncak pada titik MAP, sehingga monitor NIBP dapat membaca pulsa osilasi dan menangkap nilai sistolik dan diastolik. Untuk mencapai hal tersebut, pada studi ini dibagi lima fase pengaturan nilai PWM, sebagai berikut: (1) tekanan lebih besar titik awal osilasi $(20 \mathrm{mmHg}$ di atas nilai sistolik), tidak ada osilasi (PWM =0); (2) tekanan $20 \mathrm{mmHg}$ di atas nilai sistolik sampai tekanan sistolik, nilai PWM bertambah secara linier tergantung nilai tekanannya; (3) nilai sistolik sampai dengan MAP, PWM bertambah secara linier juga dengan laju kenaikan yang berbeda; (4) MAP sampai dengan nilai diastolik, PWM berkurang secara linier; (5) diastolik sampai dengan selesainya pengukuran, PWM berkurang secara linier dengan laju penurunan yang berbeda.

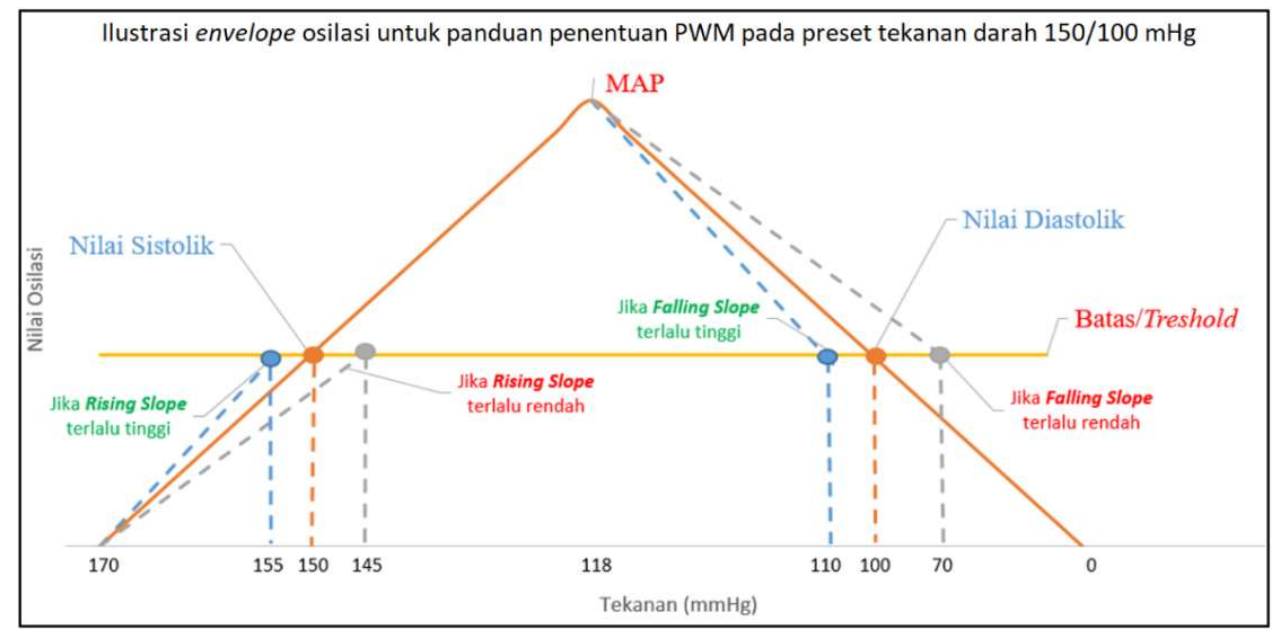

Gambar 7. Skenario Tentang Bagaimana Nibp Monitor Mencatat Nilai Sistolik dan Diastolik dari Kumpulan Gelombang Osilasi 
Skema pada Gambar 7 merupakan ilustrasi asumsi panduan penetapan PWM pada preset tekanan 150/100, di mana simulator akan mulai memberikan osilasi pada tekanan $20 \mathrm{mmHg}$ di atas nilai sistolik $(170 \mathrm{mmHg})$.

Untuk membentuk gelombang osilasi berbentuk gunung, maka nilai PWM yang diberikan harus bertambah besar untuk setiap turunnya nilai tekanan (rising slope). Pada modus naik, jika rising slope terlalu tinggi maka nilai osilasi (garis berwarna oranye) akan terlebih dahulu menyentuh garis batas/threshold (garis asumsi pengambilan nilai sistolik/diastolik), sehingga nilai sistolik akan jatuh di atas nilai target sistolik dan begitupun sebaliknya.

Setelah titik MAP, nilai PWM yang diberikan harus berkurang untuk setiap turunnya nilai tekanan (falling slope). Menyerupai konsep rising slope sebelumnya, untuk titik MAP hingga titik diastolik, jika falling slope terlalu tinggi, maka nilai osilasi akan terlebih dahulu melewati garis batas dan menyebabkan nilai akhir diastolik akan jatuh di atas nilai target diastolik dan sebaliknya.

Pada nilai tekanan tertentu, jika nilai PWM yang diberikan terlalu kecil, motor tidak akan berputar karena jumlah tekanan di luar motor jauh lebih besar dibandingkan dengan daya yang diberikan. Di sisi lain, jika daya yang diberikan terlalu besar, nilai tekanan tidak dapat turun saat proses deflasi karena tekanan yang diberikan terlalu besar.

Untuk menghasilkan osilasi yang sesuai untuk tiap preset, rangkaian nilai PWM yang diberikan berbeda. Tetapi untuk preset yang sama, rangkaian nilai PWM akan sama untuk semua merek NIBP monitor.

\subsection{Validasi Simulator yang Dikembangkan}

Proses validasi dibagi menjadi dua bagian; bagian pertama dilakukan dengan membandingkan hasil dengan nilai referensi (simulator FLUKE Biomedical), bagian kedua dilakukan dengan membandingkan hasil dengan nilai set (sesuai dengan preset darah standar). Pada bagian pertama, sejumlah 30 hasil diambil untuk setiap 5 preset tekanan darah standar menggunakan simulator referensi yang terhubung ke setiap monitor NIBP. Hasil rata-rata dari nilai-nilai sistolik, nilai-nilai diastolik, dan laju denyut dibandingkan dengan hasil menggunakan simulator yang dikembangkan. Pada bagian kedua, hasil dari simulator secara langsung dibandingkan dengan nilai set standar preset BP. Persentase kesalahan antara nilai rata-rata yang telah dihitung diambil sebagai uji akurasi, dan nilai standar deviasi antara hasil pengukuran simulator yang dikembangkan juga diambil sebagai uji pengulangan.

\subsection{Evaluasi Simulator yang Dikembangkan}

Menurut metode yang dikembangkan pada penelitian Gersak dkk (2009), proses evaluasi simulator yang dikembangkan dapat dibagi menjadi dua kondisi, kondisi statis dan dinamis. Dalam kondisi statis, menyerupai metode kalibrasi sensor tekanan sebelumnya, sensor tekanan dalam simulator yang dikembangkan dievaluasi sekali lagi menggunakan sphygmomanometer merkuri manual. Dalam kondisi dinamis, stabilitas output simulator ditentukan dari kemampuan perangkat untuk menghasilkan serangkaian amplitudo pulsa tekanan yang sama dalam interval waktu 30 detik sementara tekanan manset dipertahankan pada tingkat tekanan tertentu. Tes pengulangan output simulator yang dikembangkan juga diambil dengan membandingkan bentuk kemiringan dan pola setiap gelombang osilasi yang dihasilkan dari tiga kali pengukuran yang berbeda untuk setiap monitor NIBP pada tingkat preset tekanan darah tertentu (Geršak, Žemva, \& Drnovšek, 2009). 


\section{HASIL DAN PEMBAHASAN}

\subsection{Validasi Tensimeter Otomatis}

Tabel 1 menunjukkan hasil validasi tensimeter otomatis yang diuji dalam penelitian ini. Tiap pengujian T1 dan T2 merupakan rata-rata dari 20 kali pengukuran. Terlihat pada uji akurasi pertama dan kedua, perangkat ABN, OMRON, dan Dr. Care dapat dikategorikan baik yang dapat dilihat dari nilai kesalahan masih dalam rentang toleransi $( \pm 3 \mathrm{mmHg})$. Namun, perangkat Family Dr menunjukkan beberapa hasil yang kurang memuaskan karena nilai error untuk tekanan diastolik normal berada di luar batas rentang toleransi. Dari kedua tes dan menurut standar BSI, Family Dr. tidak cukup andal untuk digunakan dalam penelitian lebih lanjut. Tetapi, hasil dari semua perangkat menunjukkan pengulangan yang baik (perbedaan di bawah $1 \mathrm{mmHg}$ ) antara pengukuran. Oleh karena itu, perangkat Family Dr. masih dapat diterima untuk digunakan dalam penelitian lebih lanjut.

Tabel 1. Validasi Tensimeter Otomatis

\begin{tabular}{|c|c|c|c|c|c|c|c|c|c|c|c|}
\hline \multirow{2}{*}{$\begin{array}{c}\text { NIBP } \\
\text { Monitor }\end{array}$} & \multirow{2}{*}{$\begin{array}{l}\text { Tekanan } \\
\text { (mmHg) }\end{array}$} & \multicolumn{5}{|c|}{ Neonatal $(70 / 40 \mathrm{mmHg})$} & \multicolumn{5}{|c|}{ Normal (120/80 mmHg) } \\
\hline & & $\begin{array}{l}\text { Tes } 1 \\
\text { (T1) }\end{array}$ & Error & $\begin{array}{c}\text { Tes } 2 \\
\text { (T2) }\end{array}$ & Error & $\begin{array}{l}\text { Selisih } \\
\text { T1-T2 }\end{array}$ & $\begin{array}{c}\text { Tes } 1 \\
\text { (T1) }\end{array}$ & Error & $\begin{array}{l}\text { Tes } 2 \\
\text { (T2) }\end{array}$ & Error & $\begin{array}{c}\text { Selisih } \\
\text { T1-T2 }\end{array}$ \\
\hline \multirow{2}{*}{ ABN } & Sistolik & $68 \pm 0$ & 2 & $68 \pm 0$ & 2 & 0 & $119 \pm 1$ & 1 & $118 \pm 1$ & 2 & 1 \\
\hline & Diastolik & $42 \pm 0$ & 2 & $42 \pm 1$ & 2 & 0 & $79 \pm 0$ & 1 & $79 \pm 1$ & 1 & 0 \\
\hline \multirow{2}{*}{ OMRON } & Sistolik & $72 \pm 0$ & 2 & $72 \pm 0$ & 2 & 0 & $117 \pm 0$ & 3 & $117 \pm 1$ & 3 & 0 \\
\hline & Diastolik & $39 \pm 0$ & 1 & $39 \pm 0$ & 1 & 0 & $82 \pm 1$ & 2 & $82 \pm 1$ & 2 & 0 \\
\hline \multirow{2}{*}{ Dr.Care } & Sistolik & $69 \pm 1$ & 1 & $69 \pm 1$ & 1 & 0 & $121 \pm 0$ & 1 & $121 \pm 1$ & 1 & 0 \\
\hline & Diastolik & $42 \pm 1$ & 2 & $41 \pm 0$ & 1 & 1 & $80 \pm 1$ & 0 & $81 \pm 1$ & 1 & 1 \\
\hline \multirow{2}{*}{$\begin{array}{c}\text { Family } \\
\text { Dr. }\end{array}$} & Sistolik & $73 \pm 1$ & 3 & $72 \pm 0$ & 2 & 1 & $118 \pm 1$ & 2 & $118 \pm 1$ & 2 & 0 \\
\hline & Diastolik & $43 \pm 0$ & 3 & $43 \pm 1$ & 3 & 0 & $76 \pm 0$ & 4 & $76 \pm 0$ & 4 & 0 \\
\hline
\end{tabular}

\subsection{Kalibrasi Sensor Tekanan}

Sensor tekanan dikalibrasi sebanyak tiga kali untuk setiap $2 \mathrm{mmHg}$ dari 0 hingga $300 \mathrm{mmHg}$. Hasil kalibrasi sensor tekanan dapat dilihat pada grafik tekanan terhadap tegangan pada Gambar 8.

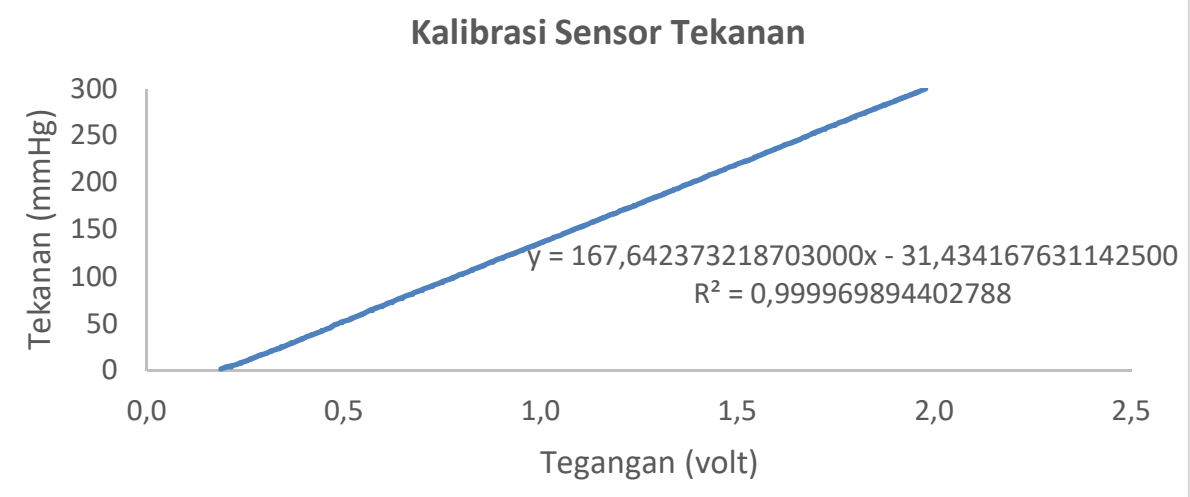

Gambar 8. Grafik Tekanan Terhadap Tegangan pada Kalibrasi Sensor Tekanan 
Nilai koefisien determinasi $\left(R^{2}\right)$ sangat mendekati 1 , yang menunjukkan korelasi yang baik antara persamaan hasil regresi dengan hasil pengukuran. Oleh karena itu, persamaan dari regresi linier pada grafik di Gambar 8 dapat digunakan untuk mengubah nilai input tegangan menjadi nilai tekanan.

\subsection{Analisis Data Referensi}

\subsubsection{Karakterisasi Denyut Nadi}

Karakterisasi laju denyut dari simulator referensi diambil untuk menentukan waktu yang diperlukan untuk sinyal osilasi naik (puncak) dan turun (lembah). Sejumlah 30 karakteristik osilasi dengan 80 bpm, masing-masing 10 data dari preset 100/65 (80 bpm), 120/80 (80 bpm), dan 150/100 (80 bpm) menggunakan monitor $A B N$, diambil untuk fokus utama dalam karakterisasi motor. Laju denyut 80 bpm dipilih karena laju 80 bpm biasa digunakan untuk beberapa preset tekanan darah standar. Waktu yang dibutuhkan untuk turun (OFF), naik (ON), dan total (satu siklus ON-OFF) dianalisis dari 12 siklus pertama. Gambar 9 menyajikan ilustrasi total durasi waktu rata-rata 80 denyut per menit dari puncak ke lembah (turun), lembah ke puncak (naik), dan waktu total untuk satu siklus penuh.

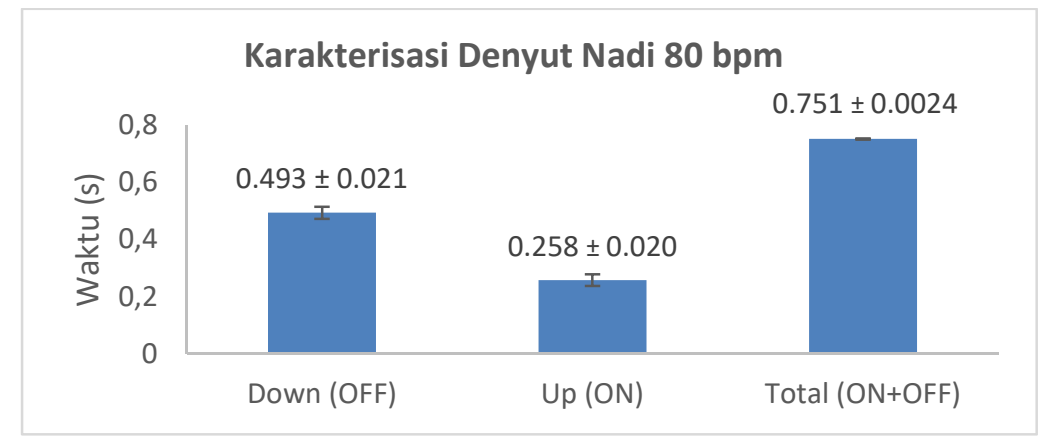

Gambar 9. Grafik Karakterisasi Denyut Nadi 80 bpm

Dari gambar 9 di atas, total waktu yang diperlukan untuk melakukan satu pulsa osilasi dengan laju denyut $80 \mathrm{bpm}$ adalah 0,751 detik (751 milidetik) berdasarkan simulator referensi. Hasil ini mendekati nilai teoritis $80 \mathrm{bpm}$ sesuai dengan rumus 60.000 (milidetik dalam satu menit) dibagi dengan 80 bpm yang setara dengan 750 milidetik (Matthies, 2014). Nilai dari hasil yang ditunjukkan di atas dibulatkan menjadi 0,250 detik (250ms) dan 0,500 detik (500ms) untuk kemudian digunakan sebagai waktu jeda osilasi antara motor ON dan motor OFF.

\subsubsection{Analisis Karakteristik Osilasi}

Tabel 2 menunjukkan karakteristik masing-masing tensimeter otomatis (NIBP monitor) berdasarkan 4 poin penting: titik awal, titik akhir, MAP, dan laju deflasi/inflasi. NIBP monitor merek Family Dr. menggunakan mode inflating yang menganalisis gelombang osilasi (mengukur tekanan darah) ketika proses pemompaan manset, sehingga nilai titik awal osilasi jauh berbeda dari NIBP monitor lainnya.

Menurut penelitian awal yang telah dilakukan oleh Fuad Ughi dan Gregorius Alvin Dewanto titik awal osilasi yang dibuat oleh simulator NIBP adalah $20 \mathrm{mmHg}$ di atas titik sistolik (Ughi \& Dewanto, 2017). Menurut Tabel 2, osilasi dimulai di atas titik sistolik tetapi masih terletak sedikit di bawah titik $20 \mathrm{mmHg}$ di atas titik sistolik. Hal ini disebabkan oleh perbedaan tingkat deflasi dari setiap monitor NIBP. Tingkat deflasi monitor OMRON adalah yang tertinggi di setiap preset tekanan darah di antara semua merek lain dari monitor NIBP tipe-deflating. Oleh karena laju yang dimiliki terlalu cepat, titik awal program simulator (yang seharusnya $20 \mathrm{mmHg}$ di atas titik sistolik) tidak dapat mengikuti kecepatan tekanan saat mengempis, sehingga titik awal lebih rendah yang dapat dilihat dari bagan di atas. Oleh karena itu, untuk preset yang 
sama, karena titik awal dari masing-masing monitor lain berbeda (besarnya standar deviasi), hasil di atas tidak dapat digunakan sebagai titik awal standar untuk program simulator, karena dapat dipengaruhi oleh tingkat deflasi yang berbeda. Dengan demikian, untuk preset tekanan darah yang sama, dapat disimpulkan bahwa osilasi yang diberikan oleh simulator harus mulai di atas titik sistolik, yang umumnya adalah $20 \mathrm{mmHg}$ di atas titik sistolik.

Tabel 2. Analisis Data Referensi dari 4 NIBP Monitor Berbeda

\begin{tabular}{|c|c|c|c|c|c|}
\hline \multirow[b]{2}{*}{ Preset } & \multirow[b]{2}{*}{ Analisis } & \multicolumn{4}{|c|}{ NIBP monitor } \\
\hline & & $\begin{array}{c}\text { ABN } \\
\text { (deflating) }\end{array}$ & $\begin{array}{c}\text { OMRON } \\
\text { (deflating) }\end{array}$ & $\begin{array}{c}\text { Dr. Care } \\
\text { (deflating) }\end{array}$ & $\begin{array}{l}\text { Family Dr. } \\
\text { (inflating) }\end{array}$ \\
\hline \multirow{4}{*}{$\begin{array}{c}80 / 50 \\
(80 \mathrm{bpm})\end{array}$} & Titik Awal (mmHg) & $97 \pm 2$ & $96 \pm 3$ & $98 \pm 1$ & $9 \pm 0$ \\
\hline & Titik Akhir (mmHg) & $39 \pm 1$ & $29 \pm 1$ & $47 \pm 1$ & $89 \pm 1$ \\
\hline & MAP (mmHg) & $62 \pm 1$ & $61 \pm 2$ & $62 \pm 1$ & $63 \pm 2$ \\
\hline & $\begin{array}{l}\text { Laju Inflasi/Deflasi } \\
\text { (mmHg/s) }\end{array}$ & $5 \pm 0$ & $10 \pm 0$ & $4 \pm 0$ & $5 \pm 0$ \\
\hline \multirow{4}{*}{$\begin{array}{l}100 / 65 \\
(80 \text { bpm) }\end{array}$} & Titik Awal (mmHg) & $117 \pm 2$ & $110 \pm 3$ & $117 \pm 1$ & $10 \pm 1$ \\
\hline & Titik Akhir (mmHg) & $50 \pm 1$ & $37 \pm 2$ & $60 \pm 1$ & $107 \pm 1$ \\
\hline & MAP (mmHg) & $78 \pm 1$ & $77 \pm 3$ & $78 \pm 2$ & $79 \pm 1$ \\
\hline & $\begin{array}{c}\text { Laju Inflasi/Deflasi } \\
\text { (mmHg/s) }\end{array}$ & $6 \pm 0$ & $11 \pm 0$ & $5 \pm 0$ & $5 \pm 0$ \\
\hline \multirow{4}{*}{$\begin{array}{c}120 / 80 \\
(80 \text { bpm) }\end{array}$} & Titik Awal (mmHg) & $135 \pm 3$ & $128 \pm 4$ & $137 \pm 2$ & $9 \pm 1$ \\
\hline & Titik Akhir (mmHg) & $61 \pm 2$ & $46 \pm 1$ & $72 \pm 1$ & $127 \pm 1$ \\
\hline & MAP (mmHg) & $95 \pm 2$ & $94 \pm 2$ & $95 \pm 2$ & $97 \pm 2$ \\
\hline & $\begin{array}{c}\text { Laju Inflasi/Deflasi } \\
\text { (mmHg/s) }\end{array}$ & $8 \pm 0$ & $13 \pm 0$ & $6 \pm 0$ & $5 \pm 0$ \\
\hline \multirow{4}{*}{$\begin{array}{l}150 / 100 \\
(80 \mathrm{bpm})\end{array}$} & Titik Awal (mmHg) & $163 \pm 3$ & $158 \pm 3$ & $162 \pm 7$ & $9 \pm 0$ \\
\hline & Titik Akhir (mmHg) & $77 \pm 1$ & $71 \pm 2$ & $93 \pm 1$ & $157 \pm 1$ \\
\hline & MAP (mmHg) & $120 \pm 2$ & $118 \pm 3$ & $119 \pm 2$ & $119 \pm 1$ \\
\hline & $\begin{array}{c}\text { Laju Inflasi/Deflasi } \\
\text { (mmHg/s) }\end{array}$ & $9 \pm 0$ & $12 \pm 0$ & $7 \pm 0$ & $5 \pm 0$ \\
\hline \multirow{4}{*}{$\begin{array}{l}200 / 150 \\
(80 \mathrm{bpm})\end{array}$} & Titik Awal (mmHg) & $210 \pm 3$ & $207 \pm 3$ & $219 \pm 2$ & $9 \pm 1$ \\
\hline & Titik Akhir (mmHg) & $118 \pm 2$ & $92 \pm 2$ & $141 \pm 2$ & $207 \pm 1$ \\
\hline & MAP (mmHg) & $170 \pm 2$ & $169 \pm 4$ & $170 \pm 2$ & $171 \pm 2$ \\
\hline & $\begin{array}{c}\text { Laju Inflasi/Deflasi } \\
(\mathrm{mmHg} / \mathrm{s})\end{array}$ & $10 \pm 0$ & $13 \pm 0$ & $7 \pm 0$ & $5 \pm 0$ \\
\hline \multirow{4}{*}{$\begin{array}{c}120 / 80 \\
(100 \mathrm{bpm})\end{array}$} & Titik Awal (mmHg) & $136 \pm 2$ & $132 \pm 2$ & $139 \pm 1$ & $9 \pm 1$ \\
\hline & Titik Akhir (mmHg) & $64 \pm 1$ & $55 \pm 1$ & $77 \pm 1$ & $126 \pm 1$ \\
\hline & MAP (mmHg) & $96 \pm 1$ & $93 \pm 2$ & $95 \pm 1$ & $97 \pm 1$ \\
\hline & $\begin{array}{l}\text { Laju Inflasi/Deflasi } \\
\text { (mmHg/s) }\end{array}$ & $7 \pm 0$ & $12 \pm 0$ & $6 \pm 0$ & $5 \pm 0$ \\
\hline
\end{tabular}

Untuk preset tekanan darah yang sama, terdapat perbedaan besar pada titik akhir osilasi dari setiap NIBP monitor yang digunakan. Hal ini dapat terjadi karena hasil yang ditunjukkan di atas diambil ketika osilasi dalam grafik telah berakhir, yakni ketika setiap NIBP monitor telah menampilkan atau mendapatkan nilai sistolik dan diastolik. Oleh karena itu, hasil tersebut tidak dapat digunakan sebagai titik akhir standar untuk menentukan kapan osilasi yang diberikan harus berhenti. 
Untuk analisis nilai MAP dilakukan untuk menentukan nilai tekanan di mana amplitudo osilasi tertinggi terjadi (tekanan arteri rata-rata) dari masing-masing preset tekanan darah. Berdasarkan karakteristik simulator referensi, hanya terdapat perbedaan kecil antara setiap pengukuran nilai MAP (standar deviasi kecil) dengan menggunakan monitor tekanan darah yang berbeda. Dengan demikian, dapat disimpulkan bahwa nilai-nilai MAP tergolong unik untuk setiap preset tekanan darah.

\subsection{Validasi Simulator yang Dikembangkan}

Sejumlah 30 data diambil dengan menggunakan 4 merk monitor NIBP yang berbeda menggunakan simulator yang dikembangkan dan simulator referensi. Hasil nilai rata-rata dari simulator yang dikembangkan kemudian dibandingkan dengan nilai set (Error Set. - Sim.) dan nilai referensi (Error Ref.- Sim.). Standar deviasi dari 30 data sistolik, diastolik, dan laju denyut kemudian dihitung untuk menentukan performa pengulangan dari hasil simulator yang dikembangkan.

Tabel 3. Validasi Simulator yang Dikembangkan (80/50 dan $100 / 65)$

\begin{tabular}{|c|c|c|c|c|c|c|c|}
\hline \multirow[b]{2}{*}{$\begin{array}{l}\text { Monitor } \\
\text { NIBP }\end{array}$} & \multirow[b]{2}{*}{ Analisis } & \multicolumn{3}{|c|}{$80 / 50$} & \multicolumn{3}{|c|}{$100 / 65$} \\
\hline & & $\begin{array}{l}\text { Sistolik } \\
\text { (mmHg) }\end{array}$ & $\begin{array}{l}\text { Diastolik } \\
\text { (mmHg) }\end{array}$ & $\begin{array}{l}\text { denyut } \\
\text { (bpm) }\end{array}$ & $\begin{array}{c}\text { Sistolik } \\
\text { (mmHg) }\end{array}$ & $\begin{array}{l}\text { Diastolik } \\
\text { (mmHg) }\end{array}$ & $\begin{array}{l}\text { denyut } \\
\text { (bpm) }\end{array}$ \\
\hline \multirow{6}{*}{$A B N$} & Nilai Set & 80 & 50 & 80 & 100 & 65 & 80 \\
\hline & Nilai Referensi & 77 & 49 & 80 & 99 & 63 & 80 \\
\hline & Nilai Simulator & 79 & 51 & 80 & 100 & 66 & 80 \\
\hline & Standar Deviasi & 1 & 1 & 0 & 1 & 1 & 0 \\
\hline & Error (Set. - Sim.) & 1 & 1 & 0 & 0 & 1 & 0 \\
\hline & Error (Ref. - Sim.) & 2 & 2 & 0 & 1 & 3 & 0 \\
\hline \multirow{6}{*}{ OMRON } & Nilai Set & 80 & 50 & 80 & 100 & 65 & 80 \\
\hline & Nilai Referensi & 77 & 51 & 80 & 98 & 65 & 80 \\
\hline & Nilai Simulator & 81 & 50 & 80 & 101 & 63 & 80 \\
\hline & Standar Deviasi & 1 & 1 & 1 & 1 & 1 & 1 \\
\hline & Error (Set. - Sim.) & 1 & 0 & 0 & 1 & 2 & 0 \\
\hline & Error (Ref. - Sim.) & 4 & 1 & 0 & 3 & 2 & 0 \\
\hline \multirow{6}{*}{ Dr. Care } & Nilai Set & 80 & 50 & 80 & 100 & 65 & 80 \\
\hline & Nilai Referensi & 81 & 51 & 80 & 93 & 64 & 80 \\
\hline & Nilai Simulator & 80 & 50 & 80 & 98 & 66 & 80 \\
\hline & Standar Deviasi & 1 & 0 & 0 & 1 & 0 & 0 \\
\hline & Error (Set. - Sim.) & 1 & 0 & 0 & 2 & 1 & 0 \\
\hline & Error (Ref. - Sim.) & 1 & 1 & 0 & 5 & 2 & 0 \\
\hline \multirow{6}{*}{$\begin{array}{l}\text { Family } \\
\text { Dr. }\end{array}$} & Nilai Set & 80 & 50 & 80 & 100 & 65 & 80 \\
\hline & Nilai Referensi & 80 & 52 & 80 & 98 & 64 & 80 \\
\hline & Nilai Simulator & 81 & 52 & 80 & 101 & 63 & 80 \\
\hline & Standar Deviasi & 1 & 1 & 0 & 1 & 1 & 0 \\
\hline & Error (Set. - Sim.) & 1 & 2 & 0 & 1 & 2 & 0 \\
\hline & Error (Ref. - Sim.) & 1 & 0 & 0 & 3 & 1 & 0 \\
\hline
\end{tabular}


Darwongso dkk.

Tabel 4. Validasi Simulator yang Dikembangkan $(120 / 80,150 / 100$, dan $200 / 150)$

\begin{tabular}{|c|c|c|c|c|c|c|c|c|c|c|}
\hline \multirow{2}{*}{$\begin{array}{l}\text { Monitor } \\
\text { NIBP }\end{array}$} & \multirow[b]{2}{*}{ Analisis } & \multicolumn{3}{|c|}{$120 / 80$} & \multicolumn{3}{|c|}{$150 / 100$} & \multicolumn{3}{|c|}{$200 / 150$} \\
\hline & & Sis & Dia & BPM & Sis & Dia & BPM & Sis & Dia & BPM \\
\hline \multirow{6}{*}{$A B N$} & Nilai Set & 120 & 80 & 80 & 150 & 100 & 80 & 200 & 150 & 80 \\
\hline & Nilai Referensi & 119 & 78 & 80 & 148 & 98 & 80 & 199 & 146 & 80 \\
\hline & Nilai Simulator & 118 & 81 & 80 & 150 & 101 & 80 & 200 & 150 & 80 \\
\hline & Standar Deviasi & 1 & 1 & 0 & 2 & 1 & 0 & 2 & 1 & 0 \\
\hline & Error (Set. - Sim.) & 2 & 1 & 0 & 0 & 1 & 0 & 0 & 1 & 0 \\
\hline & Error (Ref. - Sim.) & 1 & 3 & 0 & 2 & 3 & 0 & 1 & 4 & 0 \\
\hline \multirow{6}{*}{ OMRON } & Nilai Set & 120 & 80 & 80 & 150 & 100 & 80 & 200 & 150 & 80 \\
\hline & Nilai Referensi & 118 & 80 & 80 & 147 & 102 & 80 & 198 & 151 & 80 \\
\hline & Nilai Simulator & 119 & 80 & 80 & 150 & 100 & 80 & 199 & 150 & 80 \\
\hline & Standar Deviasi & 2 & 1 & 1 & 2 & 1 & 0 & 2 & 1 & 1 \\
\hline & Error (Set. - Sim.) & 1 & 0 & 0 & 0 & 0 & 0 & 1 & 0 & 0 \\
\hline & Error (Ref. - Sim.) & 2 & 0 & 0 & 3 & 2 & 0 & 2 & 1 & 0 \\
\hline \multirow{6}{*}{ Dr. Care } & Nilai Set & 120 & 80 & 80 & 150 & 100 & 80 & 200 & 150 & 80 \\
\hline & Nilai Referensi & 121 & 80 & 80 & 141 & 98 & 80 & 199 & 150 & 80 \\
\hline & Nilai Simulator & 120 & 80 & 80 & 149 & 100 & 80 & 199 & 149 & 80 \\
\hline & Standar Deviasi & 0 & 0 & 0 & 1 & 1 & 0 & 0 & 0 & 0 \\
\hline & Error (Set. - Sim.) & 0 & 0 & 0 & 1 & 0 & 0 & 1 & 1 & 0 \\
\hline & Error (Ref. - Sim.) & 1 & 0 & 0 & 8 & 2 & 0 & 1 & 1 & 0 \\
\hline \multirow{6}{*}{ Family Dr. } & Nilai Set & 120 & 80 & 80 & 150 & 100 & 80 & 200 & 150 & 80 \\
\hline & Nilai Referensi & 117 & 77 & 80 & 146 & 98 & 80 & 196 & 154 & 80 \\
\hline & Nilai Simulator & 121 & 77 & 80 & 150 & 98 & 80 & 202 & 151 & 80 \\
\hline & Standar Deviasi & 1 & 1 & 0 & 1 & 1 & 0 & 1 & 1 & 0 \\
\hline & Error (Set. - Sim.) & 1 & 3 & 0 & 0 & 2 & 0 & 2 & 1 & 0 \\
\hline & Error (Ref. - Sim.) & 4 & 0 & 0 & 4 & 0 & 0 & 6 & 3 & 0 \\
\hline
\end{tabular}

Dari hasil validasi pada Tabel 3 dan Tabel 4, hasil uji pengulangan tergolong sangat baik yang dapat dilihat dari nilai standar deviasi yang tergolong sangat kecil antara setiap pengukuran yang diambil dengan menggunakan simulator yang dikembangkan. Namun untuk beberapa nilai sistolik dan diastolik, error melebihi batas $\pm 3 \mathrm{mmHg}$ (sesuai standar SNI IEC 806012:30:2014). Hal ini dapat terjadi karena pada saat pembuatan program simulator, hasil yang dituju lebih mengikuti nilai set, yang dapat ditunjukkan dari nilai error antara nilai set dan nilai simulator yang sangat baik (dibawah $\pm 3 \mathrm{mmHg}$ ). Selain itu, pada nilai-nilai error tersebut, hasil evaluasi selisih nilai referensi dengan nilai set melebihi $3 \mathrm{mmHg}$.

Selain itu, motor pompa yang digunakan terkadang tidak memberikan performa yang sama, yang mengakibatkan motor tidak sepenuhnya berputar dalam kondisi tekanan tertentu, terutama dengan nilai PWM rendah di titik awal yang dapat mengakibatkan perbedaan hasil sistolik dan diastolik. Perlu diingat juga bahwa NIBP monitor pun memiliki kesalahan yang dapat mempengaruhi hasil validasi simulator. 


\subsection{Evaluasi Simulator yang Dikembangkan}

Evaluasi dari simulator yang dikembangkan dilakukan dalam dua kondisi, kondisi statis dan dinamis. Untuk kondisi statis, sensor tekanan dievaluasi kembali (dengan pembanding tensimeter manual merkuri) setelah digunakan selama lima bulan dan hasilnya dibandingkan dengan hasil dari kalibrasi sensor tekanan yang telah dilakukan pada fase awal studi. Menurut hasil evaluasi yang diilustrasikan oleh grafik pada Gambar 10 , nilai koefisien determinasi $\left(R^{2}\right)$ sangat dekat dengan nilai 1 dan nilai persentase kesalahan antara kedua hasil tergolong kecil, yakni di bawah $5 \%$ kesalahan untuk setiap tingkat tekanan yang menunjukkan bahwa sensor tekanan masih dalam kondisi baik setelah digunakan selama 5 bulan.

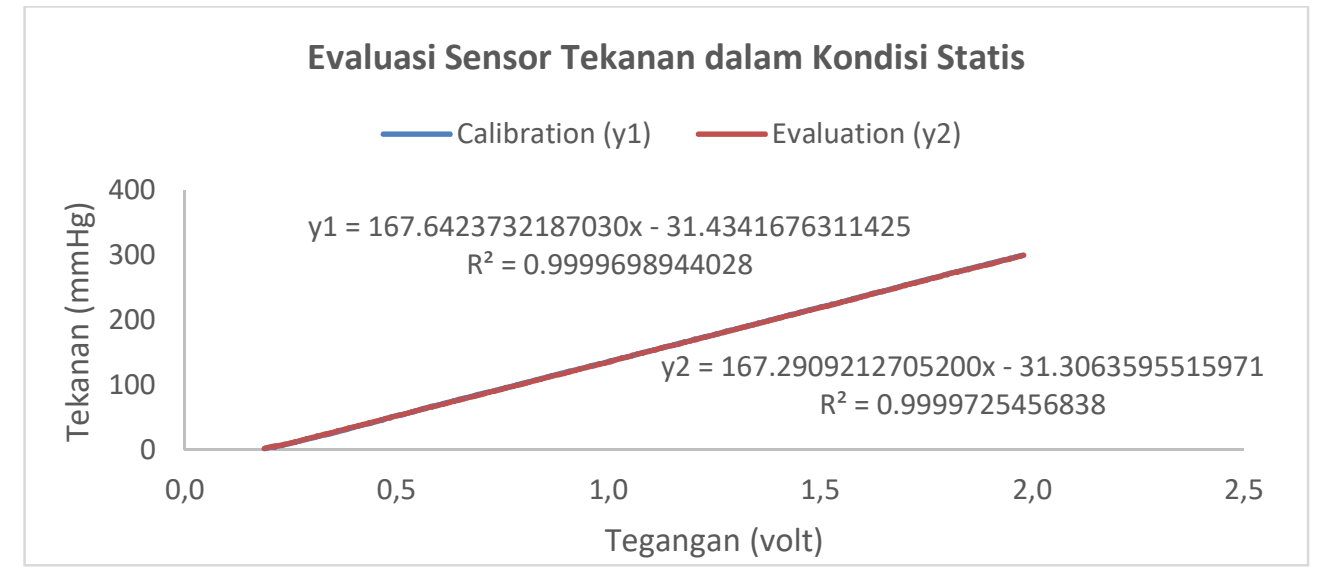

Gambar 10. Evaluasi Sensor Tekanan dalam Kondisi Statis (Tekanan Terhadap Tegangan)

Untuk evaluasi dalam kondisi dinamis, stabilitas hasil simulator yang dikembangkan diuji dengan mengevaluasi serangkaian puncak tekanan dalam interval waktu 30 detik. Evaluasi dilakukan dengan menggunakan perangkat $A B N$ yang diatur sedemikian rupa (dengan perbandingan laju deflasi dan nilai PWM yang sesuai) agar tekanan berkisar di nilai $99 \mathrm{mmHg}$ selama 30 detik. Stabilitas hasil simulator sangat baik yang dapat dilihat di grafik pada Gambar 11 dimana amplitudo puncak tekanan terdistribusi dengan baik dan berpusat di sekitar nilai amplitudo puncak rata-rata (Distribusi Normal/Bell-Curved), yaitu 140.431 dengan standar deviasi 0.145 . Juga, total 40 puncak juga dihasilkan oleh simulator dari durasi 30 detik yang membuktikan bahwa karakterisasi denyut nadi 80 bpm (atau 40 ketukan per setengah menit) dari motor bekerja dengan baik sesuai dengan program.

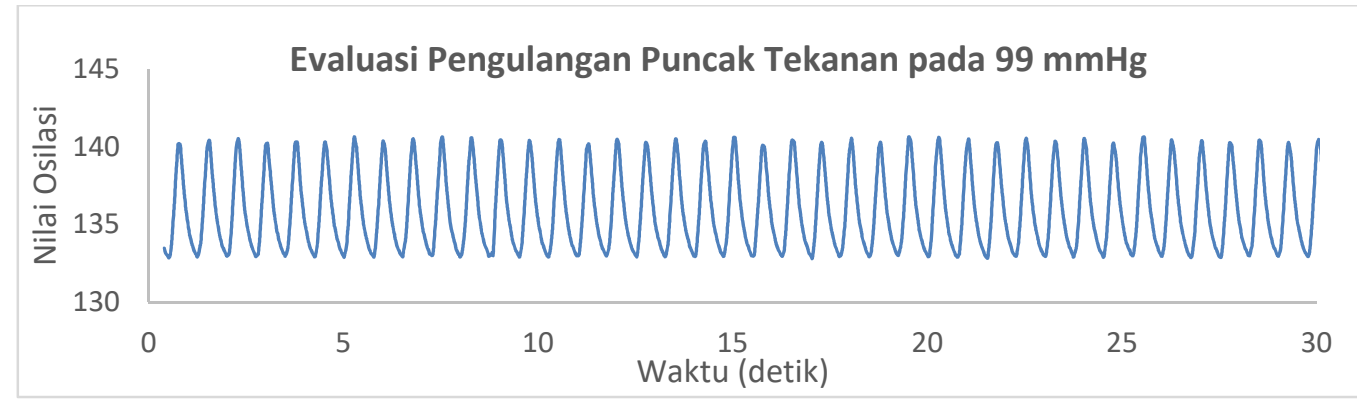

Gambar 11. Serangkaian Pulsa Tekanan Pada 99 mmhg dalam Waktu Interval 30 Detik

Uji pengulangan juga dilakukan dengan membandingkan kemiringan dan pola dari tiga bentuk gelombang osilasi yang berbeda yang dihasilkan dari setiap monitor NIBP pada preset 200/150. Hasilnya diplot menjadi grafik gabungan untuk setiap monitor NIBP, seperti ditampilkan pada grafik di Gambar 12. 


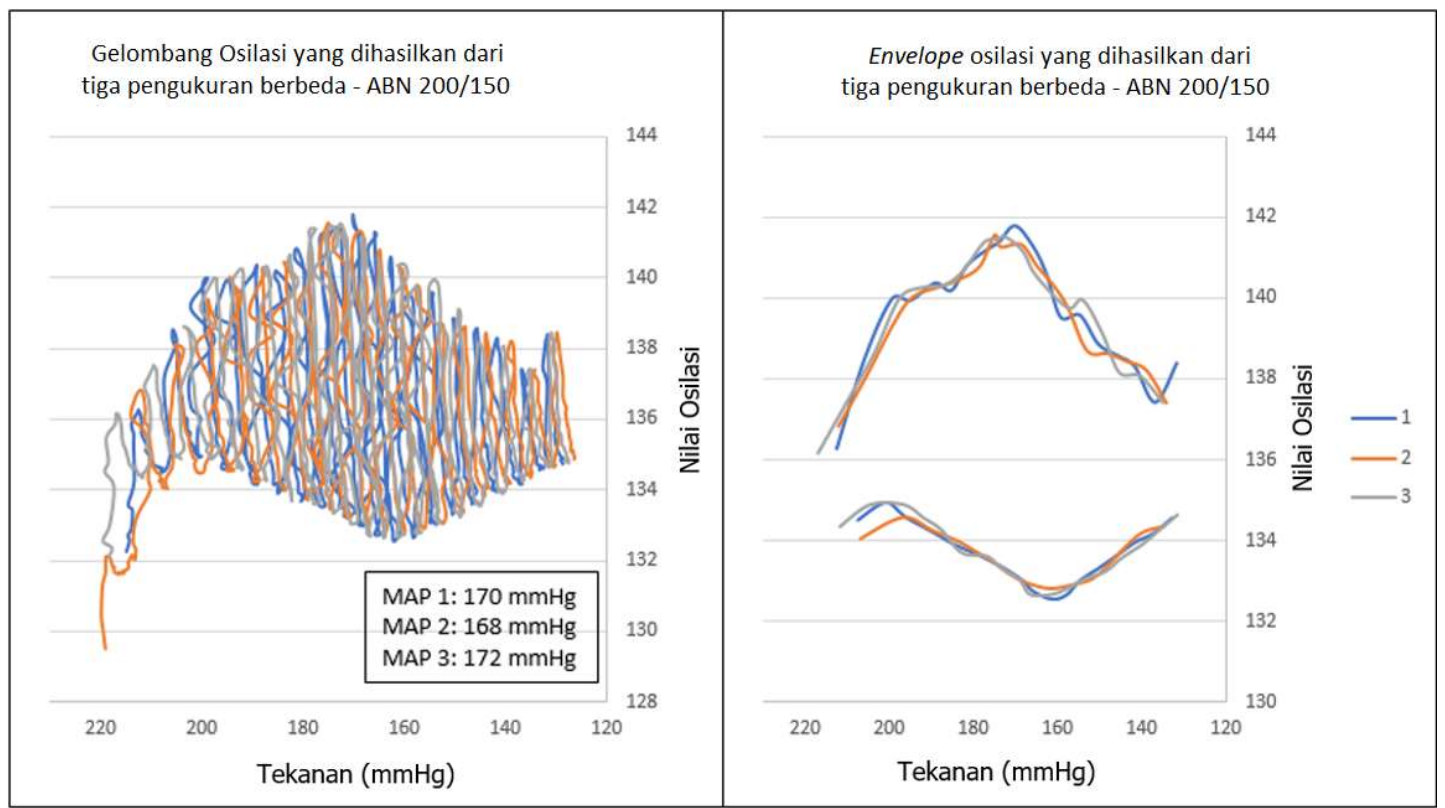

(a)

(b)

Gambar 12. Uji Pengulangan Karakteristik Osilasi. (a) Sinyal Osilasi Tiga Pengukuran Berbeda. (b) Envelope Sinyal Osilasi Tiga Pengukuran Berbeda.

Pola gelombang dan envelope sinyal dari 3 pengukuran yang berbeda menggunakan setiap monitor NIBP tergolong baik dan stabil, yang menunjukkan pengulangan dan stabilitas yang baik antara setiap simulasi yang dilakukan oleh simulator yang dikembangkan.

\section{KESIMPULAN}

Metode simulator baru berdasarkan nilai PWM, dengan mengatur kemiringan naik dan menurun sehingga membentuk envelope osilasi dengan puncak pada titik MAP berhasil dikembangkan. Program ini bekerja dengan baik dan menghasilkan simulasi yang sama untuk berbagai merek monitor NIBP, baik tipe inflating maupun deflating. Hasil validasi dengan nilainilai set, cukup memuaskan yang dapat dilihat dari error yang masih dalam rentang toleransi sesuai standar nasional (SNI IEC 80601-2:30:2014). Tetapi karena pada proses pengembangan penentuan nilai PWM lebih mengacu pada nilai set yang dibaca oleh NIBP monitor, hasil validasi dengan simulator referensi menunjukkan beberapa nilai error di atas \pm 3 $\mathrm{mmHg}$.

Evaluasi simulator yang dikembangkan telah berhasil dilakukan dalam kondisi statis dan dinamis. Untuk evaluasi statis, hasilnya menunjukkan bahwa sensor tekanan masih dalam kondisi baik setelah digunakan selama 5 bulan. Dalam kondisi dinamis, stabilitas output simulator cukup memuaskan dimana distribusi amplitudo puncak tekanan berpusat di sekitar rata-rata amplitudo $(140.5 \mathrm{mmHg})$ dengan nilai standar deviasi 0.145 . Pengulangan simulasi yang dihasilkan oleh simulator juga cukup baik dan stabil yang dapat dilihat dari pola kemiringan dan gelombang dari 3 pengukuran yang berbeda dari masing-masing monitor NIBP berdekatan satu sama lain. Dengan demikian, simulator yang dikembangkan dapat digunakan untuk pra-pemeriksaan akurasi cepat termasuk menilai karakteristik pengulangan tensimeter otomatis. 


\section{DAFTAR RUJUKAN}

Badan Standardisasi Nasional. (2014). Peralatan Elektromedik - Bagian 2-30: Persyaratan Khusus untuk keselamatan dasar dan kinerja esensial tensimeter non invasive otomatis.

Balestrieri, E., Daponte, P., \& Rapuano, S. (2009, May). Open questions on unified apporach for calibration of oscillometric blood pressure measurement devices. 2009 IEEE International Workshop on Medical Measurements and Applications (pp. 206-211). Cetraro: IEEE. doi:10.1109/MEMEA.2009.5167985

Dewanto, G. A. (2016). Development of Low Cost Blood Pressure Simulator for Automatic NonInvasive Blood Pressure Monitor. Tangerang: Swiss German University.

Geršak, G., Žemva, A., \& Drnovšek, J. (2009). A procedure for evaluation of non-invasive blood pressure simulators. Medical \& Biological Engineering \& Computing, 4712), 12211228. doi:10.1007/s11517-009-0532-2

Hogg, R. V., \& Tanis, E. A. (1977). Probability and statistical inference. New York: Macmillan. International Organization of Legal Metrology. (2002). International Recommendation OIML $R$ 16-2 . Paris: International Organization of Legal Metrology.

Matthies, A. (2014). How to convert ms (milliseconds) to BPM (beats per minute) and vice versa. Retrieved June 24, 2018, from http://guitargearfinder.com/guides/convert-msmilliseconds-bpm-beats-per-minute-vice-versa/

Santoso, N. A., \& Ughi, F. (2017). Optimization of Low Cost Blood Pressure Simulator for Automatic Noninvasive Blood Pressure Monitor. 2017 5th International Conference on Instrumentation, Communications, Information Technology, and Biomedical Engineering (pp. 152-156). Bandung: IEEE. doi:https://doi.org/10.1109/ICICIBME.2017.8537768

Ughi, F., \& Dewanto, G. A. (2017). Karakteristik Osilometrik dari Simulator Tekanan Darah. Elkomika, 5(1). doi:https://doi.org/10.26760/elkomika.v5i1.15 